Осадчук I. Ю., кандидат політичних наук, доцент кафбедри політологї

\title{
АТИПОВА НАПІВПРЕЗИДЕНТСЬКА СИСТЕМА ПРАВЛІННЯ ТА ПОЛІТИЧНИЙ РЕЖИМ У РЕСПУБЛІЦІ КАЗАХСТАН (1995-2018 PP.)
}

\begin{abstract}
Анотація. Формальні та фактичні характеристики деяких напівпрезидентських систем правління можуть сприяти формуванню i функціонуванню таких систем правління, які відрізняються від традиційних / типових напівпрезидентських. У країнах 3 атиповим напівпрезиденталізмом зазвичай функціонують недемократичні політичні режими. В цьому контексті актуальним $є$ дослідження напівпрезидентської системи правління та визначення типів політичного режиму в Республіці Казахстан у 1995-2018 pр. Метою статті $\epsilon-$ визначити особливості функціонування напівпрезидентської системи правління та типи політичного режиму в Республіці Казахстан у 1995-2018 pp. Теоретико-методологічною основою запропонованого наукового дослідження вибрано неоінституціоналізм і його варіативні типи й парадигми. Головний метод, котрий став іманентною складовою частиною дослідження, - це метод порівняльного аналізу. У представленому дослідженні ми використовуємо модифікацію типології систем державного правління Р. Елгі, розроблену українським дослідником В. Литвином, доповнену асамблейно-незалежною системою правління. Конституційні зміни в Республіці Казахстан 1998 р. передбачали скасування обмеження на переобрання президента (раніше було не більше двох разів поспіль). Ці зміни дозволили знову розпочати відлік кількості термінів і дали президенту «право» обиратися знову на «перший» термін вже за новими правилами. Відповідно до Конституції обмеження щодо перебування на посаді президента максимально два терміни поспіль не поширювалось на першого президента Республіки Казахстан. Це дало змогу Н. Назарбаєву (як першому президенту Республіки Казахстан) обиратись на посаду глави держави необмежену кількість разів. У Республіці Казахстан у 1995-2018 рр. президент мав право 3 власної ініціативи прийняти рішення про припинення повноважень уряду і звільнити 3 посади будь-якого його члена. Отже, висловлення парламентом вотуму недовіри уряду автоматично не призводило до його відставки, оскільки вона залежала від позиції / волі президента. Для визначення типів політичного режиму в Республіці Казахстан використано сучасні методики, а саме «рейтинг демократичного розвитку» (“The Democracy Score”), розроблений експертами "Freedom House" за програмою «Нації у транзиті» ("Nations in Transit") та «індекс демократії» ("Democracy Index"), що розраховується дослідницьким центром «The Economist Intelligence Unit» (аналітичний підрозділ журналу “The Economist”). На підставі рейтингу демократичного розвитку (1997-2018рр.) визначено, що політичний режим у Республіці Казахстан еволюціонував від напівконсолідованого авторитаризму до консолідованого авторитаризму. На основі індексу демократії (2006-
\end{abstract}

2018 рр.) політичний режим у Республіці Казахстан визначено як авторитарний. Крім того, на підставі дослідження Ф. Гулієва політичний режим у Республіці Казахстан (впродовж 1995-1997рр.) визначено як гегемоністський авторитаризм.

Ключові слова: система державного правління, напівпрезидентська система правління, атипова напівпрезидентська система правління, вотум недовіри уряду, політичний режим, Республіка Казахстан.

Постановка проблеми. Політична практика та формальні характеристики деяких напівпрезидентських систем правління можуть сприяти формуванню і функціонуванню таких систем правління, які відрізняються від традиційних / типових напівпрезидентських. У країнах з атиповим напівпрезиденталізмом зазвичай функціонують недемократичні політичні режими. В цьому контексті актуальним $є$ дослідження напівпрезидентської системи правління та визначення типів політичного режиму в Республіці Казахстан у 1995-2018 pp.

Аналіз останніх досліджень і публлікацій. Атипові напівпрезидентські системи правління або окремі аспекти політичного процесу та міжінституційних відносин, які прямо чи опосередковано вказують на атиповість напівпрезидентських систем правління у рамках республіканської форми державного правління, проаналізовано у працях таких авторів, як О. Зазнаєв [1], I. Осадчук [2; 3], В. Литвин [2] тощо. Політичний режим (або його окремі елементи) у Республіці Казахстан досліджували такі автори, як А. Дель Сорді [4], С. Каммінгс [5], А. Куртов [6], І. Осадчук [7], Д. Фурман [8], Е. Шатц [9] тощо.

Метою статті $\epsilon$ - визначити особливості функціонування напівпрезидентської системи правління та типи політичного режиму в Республіці Казахстан у 1995-2018 pp.

Виклад основного матеріалу. Теоретико-методологічною основою запропонованого наукового дослідження вибрано неоінституціоналізм і його варіативні типи й парадигми. Головний метод, котрий став іманентною складовою частиною дослідження, - це метод порівняльного аналізу.

Серед найапробованіших методик визначення типових конституційних і політичних систем державного правління у рамках республіканської форми державного правління варто виділити методику Р. Елгі [10; 11]. У цьому дослідженні ми використовуємо модифікацію типології систем державного правління Р. Елгі, розроблену українським дослідником В. Литвином, який визначає: а) президенталізм (президентську систему правління) - як конституційну (i/чи політичну) систему республіканської форми державного правління, якій 
властива посада всенародно (прямо / опосередковано) обраного на фіксований термін президента й інституту кабінету / адміністрації президента (навіть можливо прем'єр-міністра), члени яких колективно відповідальні винятково перед президентом (водночас члени кабінету чи адміністрації президента можуть бути й індивідуально відповідальними перед парламентом / провідною палатою парламенту (легіслатурою), однак це не має дефінітивного впливу та значення на структурування системи державного правління); б) парламентаризм (парламентську систему правління) - як конституційну (i/чи політичну) систему республіканської форми державного правління, за якої президент отримує свої повноваження на підставі непрямого (невсенародного) вибору (наприклад, у легіслатурі), а прем'єр-міністр й урядовий кабінет колективно відповідальні винятково перед легіслатурою (водночас члени уряду, крім прем'єр-міністра, можуть бути індивідуально відповідальними i перед президентом та легіслатурою, однак це не має дефінітивного значення й впливу на структурування системи державного правління); в) напівпрезиденталізм (напівпрезидентську систему правління) - як конституційну (i/чи політичну) систему республіканської форми державного правління, якій властиві посада всенародно (прямо / опосередковано) обраного на фіксований термін президента, а також інститут прем'єр-міністра й урядового кабінету, які обов'язково колективно відповідальні хоча 6 перед легіслатурою (водночас прем'єр-міністр та урядовий кабінет можуть бути одночасно колективно відповідальними і перед парламентом, і перед главою держави; навіть більше, міністри урядового кабінету можуть бути індивідуально відповідальними перед парламентом i/чи президентом, але це не має жодного дефінітивного значення та впливу на структурування системи державного правління), а також притаманний процес суміщення або дуалізації виконавчої влади, 3 одного боку, президентом (обов'язково як главою держави), а 3 іншого боку, - прем'єр-міністром (обов'язково як главою уряду) та урядом / урядовим кабінетом [12, с. 5; 13, с. 7]. Незалежно від природи та процесуальної логіки парламентського вотуму недовіри уряду i/чи прем'єр-міністру напівпрезидентською позиціонується та система державного правління, в якій $\epsilon$ «безперервна» обов'язкова колективна відповідальність уряду та прем'єр-міністра перед легіслатурою, або, інакше кажучи, в якій легіслатура володіє ініціативою ставити питання про колективну відповідальність уряду. Натомість усі інші/ додаткові уточнення та атрибути є тільки допоміжними правилами класифікації систем правління, які варто застосовувати тільки у типологізації напівпрезиденталізму [12, с. 80]. Вказану модифікацію типології систем державного правління у рамках республіканської форми державного правління ми доповнюємо асамблейно-незалежною системою правління. М. Шугарт і Дж. Кері, а також О. Зазнаєв визначають асамблейно-незалежну систему правління як систему правління, для якої характерні такі ознаки: 1) невсенародні вибори президента; 2) уряд не несе відповідальності перед парламентом [1, с. 55; 14, с. 26].

У Республіці Казахстан у 1995 р. відповідно до підсумків всенародного референдуму повноваження президента були продовжені до 1 грудня 2000 р. Конституційні зміни 1998 р. передбачали скасування обмеження на переобрання президента (раніше було не більше двох разів поспіль) [15]. Ці зміни дозволили заново розпочати відлік кількості термінів і дали президенту «право» обиратися знову на «перший» термін вже за новими правилами [16, с. 51]. Відповідно до ч. 5 ст. 42 Конституції та сама особа не може бути обрана президентом більше двох разів поспіль. Це обмеження не поширювалось на першого президента Республіки Казахстан [17]. Таким чином, Н. Назарбаєв (як перший президент Республіки Казахстан) міг обиратись на посаду глави держави необмежену кількість разів. Зазначимо, що президент обирався на всенародних (прямих) виборах.

У Республіці Казахстан в 1995-2007 pp. більшістю у дві третини голосів від загальної кількості депутатів кожної $з$ палат (Мажилісу і Сенату) парламент за ініціативою не менше однієї п'ятої від загальної кількості своїх депутатів висловлював вотум недовіри уряду (ст. 53). Причому президент впродовж десяти днів розглядав питання про прийняття або відхилення відставки уряду (ст. 70) [7; 15]. У Республіці Казахстан з 2007 р. уряд є колегіальним органом і у своїй діяльності відповідальний перед президентом та парламентом (ч. 2 ст. 64). Згідно зі ст. 70 уряд заявляє президенту про відставку у разі висловлення Мажилісом (нижньою палатою парламенту) чи загалом парламентом вотуму недовіри уряду. Президент впродовж десяти днів розглядає питання про прийняття чи відхилення відставки уряду. Прийняття відставки прем'єр-міністра означає припинення повноважень усього уряду. У разі відхилення відставки уряду президент доручає уряду подальше здійснення повноважень. При цьому президент має право з власної ініціативи прийняти рішення про припинення повноважень уряду і звільнити 3 посади будьякого його члена [17]. Отже, висловлення парламентом вотуму недовіри уряду автоматично не призводило до його відставки, оскільки вона залежала від позиції / волі президента.

Для визначення типів політичного режиму в Республіці Казахстан використовуємо сучасні методики, а саме «рейтинг демократичного розвитку» ("The Democracy Score"), розроблений експертами "Freedom House" за програмою «Нації у транзиті» ("Nations in Transit") та «індекс демократії» (“Democracy Index") - глобальне дослідження, що визначає рейтинг країн світу за показником рівня демократії. Індекс демократії розраховує дослідницький центр "Тhe Economist Intelligence Unit” (аналітичний підрозділ журналу "The Economist").

Для визначення рейтингу демократичного розвитку кожна країна за кожним з семи показників (індекси виборчого процесу, розвитку громадянського суспільства, незалежності 3МI, демократичності урядування на національному / державному рівні, демократичності урядування на місцевому рівні, незалежності судової системи, корупції) отримує свій рейтинг. Усі країни в рейтингу розташовуються за шкалою від 1 до 7 балів ( 3 використанням сотих часток), де 1 бал відповідає найвищому рівню демократичного розвитку, 7 балів - найнижчому. Загальний результат (рейтинг демократичного розвитку - сума всіх показників, поділена на 7) є визначальним під час складання підсумкового рейтингу демократичного розвитку певної країни. Враховуючи рейтинг і його значення, "Freedom House" дає таку оцінку політичному режиму тієї чи іншої країни: 1) консолідований демократичний режим $(1,00-2,99) ; 2)$ напівконсолідований демократичний режим $(3,00-3,99) ; 3)$ перехідний або гібридний режим $(4,00-4,99) ; 4)$ напівконсолідований авторитарний режим $(5,00-5,99) ; 5)$ консолідований авторитарний режим $(6,00-7,00)[18]$. 
Рейтинг демократичного розвитку в Республліці Казахстан (1997-2018рp.) [7, с. 203; 18]

\begin{tabular}{|c|c|c|c|c|c|c|c|c|c|c|c|c|c|c|c|c|c|c|c|c|c|}
\hline Рік & a & $\stackrel{\infty}{\sigma}$ & $\begin{array}{l}\text { ठे } \\
\text { dे } \\
\text { aे }\end{array}$ & Б्रे & ఫ్ & ڤ్రి & 弚 & ¿्षे & ః્ণ & ఫ్రి & ڤ్రి & ठ્ণે & $\stackrel{\circ}{\stackrel{\sim}{~}}$ & $\overline{\vec{\sim}}$ & ఫี & $\stackrel{\tilde{\Xi}}{\bar{i}}$ & $\stackrel{\vec{઼}}{\vec{\Delta}}$ & $\stackrel{\sim}{\bar{\lambda}}$ & $\stackrel{\text { ๐े }}{\bar{c}}$ & $\overline{\bar{~}}$ & $\stackrel{\infty}{\stackrel{\sim}{二}}$ \\
\hline Показник & 召 & ڤn & $\begin{array}{l}\text { 号 } \\
\text { in }\end{array}$ & $\vec{n}$ & $\stackrel{2}{\circ}$ & 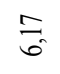 & â & तु & हुे & हुे & हु. & तु & fo & fु & 苦 & $\sqrt{n}$ & छ. & $\overrightarrow{0}$ & $\vec{\Xi}$ & ț & $\bar{E}$ \\
\hline
\end{tabular}

Індекс демократії в Респуб̆ліці Казахстан (2006-2018 рр.) [7, с. 203; 19]

Таблиця 2

\begin{tabular}{|c|c|c|c|c|c|c|c|c|c|c|c|}
\hline Рік & 2006 & 2008 & 2010 & 2011 & 2012 & 2013 & 2014 & 2015 & 2016 & 2017 & 2018 \\
\hline Показник & 3,62 & 3,45 & 3,30 & 3,24 & 2,95 & 3,06 & 3,17 & 3,06 & 3,06 & 3,06 & 2,94 \\
\hline
\end{tabular}

На підставі рейтингу демократичного розвитку (1997-2018 рр.) стверджуємо, що політичний режим у Республіці Казахстан еволюціонував від напівконсолідованого авторитаризму до консолідованого авторитаризму (табл. 1).

Індекс демократії складений з 60 ключових показників, згрупованих у п'ять основних категорій, які характеризують стан демократії всередині країни: 1) виборчий процес і плюралізм; 2) функціонування уряду; 3) політична участь; 4) політична культура; 5) громадянські свободи. Індекс демократії розраховують за шкалою від 0 до 10 балів. У підсумковому рейтингу всі країни ранжуються на підставі індексу демократії, класифікуючись за типом політичного режиму як: 1) повна демократія $(8,00-10,00) ; 2)$ дефектна демократія $(6,00-7,99) ; 3)$ гібридний режим $(4,00-5,99) ; 4)$ авторитарний режим $(<4,00)[19]$.

На основі індексу демократії (2006-2018рр.) політичний режим у Республіці Казахстан оцінюємо як авторитарний (табл. 2). Крім того, на підставі дослідження Ф. Гулієва [20], в якому автор запропонував власну методику, політичний режим у Республіці Казахстан (впродовж 1995-1997 рр.) визначено як гегемоністський авторитаризм.

Висновки. В Республіці Казахстан у 1995-2018 рр. президент мав право з власної ініціативи прийняти рішення про припинення повноважень уряду і звільнити з посади будь-якого його члена. Таким чином, висловлення парламентом вотуму недовіри уряду автоматично не призводило до його відставки, оскільки вона залежала від позиції / волі президента. Це зумовило атиповість напівпрезидентської системи правління в Республіці Казахстан у 1995-2018 рр. 3'ясовано, що впродовж вказаного періоду політичний режим у Республіці Казахстан еволюціонував від напівконсолідованого авторитаризму до консолідованого авторитаризму. У подальших дослідженнях проаналізуємо особливості функціонування атипових напівпрезидентських систем правління в інших країнах та їхні політичні режими.

\section{Jimepamypa:}

1. Зазнаев О. Атипичные президентские и полупрезидентские системы. Ученые записки Казанского государственного университета. Серия: Гуманитарные науки. 2005. Т. 147. Кн. 1. С. 54-69.

2. Осадчук I., Литвин В. Атиповість напівпрезидентських систем державного правління в пострадянських країнах: контекст вотумів недовіри урядам. Politicus. 2018. Вип. 3. С. 49-57.

3. Осадчук I. Партійні системи в контексті функціонування атипових напівпрезидентських систем правління в Республіці Казах- стан (1995-2018) і Російській Федерації (1993-2018). Politicus. 2018. Вип. 5/6. С. 66-73. DOI: 10.24195/2414-9616-2018-5-6-66-73.

4. Del Sordi A. The Party of Power of Kazakhstan: The origins, resources and regime-supporting functions of Nur Otan. PhD Program in Political Systems and Institutional Change. IMT Institute for Advanced Studies, Lucca, 2012. 220 p.

5. Cummings S. Kazakhstan: Power and the Elite. London; New York: I.B. Tauris, 2005. 202 p., [6] p.: illustrations.

6. Куртов А. Демократия выборов в Казахстане: авторитарная эволюция. Конституционное право: восточноевропейское обозрение. 2000. № 2 (31). С. 2-10.

7. Осадчук I. Порівняльний аналіз президенціалізації систем правління у Білорусі та Казахстані : дисертація на здобуття наукового ступеня кандидата політичних наук : 23.00.02. Львів : Львівський національний університет імені Івана Франка, 2014. 288 с.

8. Furman D. The Regime in Kazakhstan. Rumer B. Central Asia at the End of the Transition. Armonk, New York : Sharpe, 2005. P. 195-266.

9. Schatz E. The Soft Authoritarian Tool Kit: Agenda-Setting Power in Kazakhstan and Kyrgyzstan. Comparative Politics. 2009. Vol. 1. No. 2. P. 203-222.

10. Elgie R. A Fresh Look at Semipresidentialism: Variations on a Theme. Journal of Democracy. 2005. Vol. 16. No. 3. P. 98-112.

11. Elgie R. Presidential Power. Glossary. URL: http:// presidential-power.com/?page_id=5 (Last accessed: 27.11.2019).

12. Литвин В. Атрибути та різновиди напівпрезидентської системи правління в Європі: інституційно-процесуальний і політично-поведінковий аспекти : монографія. Львів : Львівський національний університет імені Івана Франка, 2018. 636 с.

13. Литвин В., Романюк А. Концептуалізація і теоретична дистинкція понять «форма державного правління» та «система державного правління» у політичній науці. Науковий часопис Національного педагогічного університету імені М.П. Драгоманова: Сер. 22. Політичні науки та методика викладання сочіально-політичних дисииплін. Вип. 20. Київ : Вид-во НПУ імені М.П. Драгоманова, 2016. C. 3-12.

14. Shugart M., Carey J. Presidents and Assemblies. Constitutional Design and Electoral Dynamics. Cambridge : Cambridge University Press, $1992.316 \mathrm{p}$.

15. О внесении изменений и дополнений в Конституцию Республики Казахстан: Закон Республики Казахстан от 7 октября 1998 г. № 284-I. URL: https://online.zakon.kz/Document/?doc_ $\mathrm{id}=1010769$ \#pos=0;249 (дата обращения: 27.11.2019).

16. Осадчук I. Кількість термінів президентських повноважень в контексті функціонування атипових напівпрезидентських систем правління в пострадянських країнах. Розвиток суспільних наук в сучасних умовах: теорія, методологія, практика: матеріали Міжнародної науково-практичної конференції (Київ, 18-19 жовтня 2019 р.). Київ : Таврійський національний університет імені В.I. Вернадського, 2019. С. 50-54. 
17. Конституция Республики Казахстан от 30 августа 1995 г. (с изменениями и дополнениями от 10 марта 2017 г.). URL: http:// www.akorda.kz/ru/official_documents/constitution (дата обращения: 27.11.2019).

18. Nations in Transit. Freedom House. URL: https://freedomhouse.org/ report-types/nations-transit (Last accessed: 27.11.2019).

19. Democracy Index. Economist Intelligence Unit. URL: https:// www.gapminder.org/data/documentation/democracy-index/ (Last accessed: 27.11.2019).

20. Guliyev F. Measuring Hybrid Regimes: An Alternative Measurement Method and Classification of Post-Soviet Regimes. IERES, Elliott School of International Affairs, 2012. URL: https://papers.ssrn.com/ sol3/papers.cfm?abstract_id=2349169 (Last accessed: 27.11.2019)

Osadchuk I. Atypical semi-presidential system of government and political regime in the Republic of Kazakhstan (1995-2018)

Summary. The author analyzed the systems of government within the framework of a republican form of government. In modern Political Science, researchers distinguish both typical and atypical semi-presidential systems of government. Atypical semi-presidential systems of government in the Post-Soviet countries requires a detailed analysis in Political Science. In this context, the analysis of semi-presidential system of government in the Republic of Kazakhstan (in 1995-2018) is extremely actual. In atypical semi-presidential countries, as a rule, undemocratic political regimes are functioning. New institutionalism and its various types and paradigms are chosen as theoretical and methodological basis of the proposed research. The main method of the study is the method of comparative analysis. Their combination made it possible to work out a coherent picture of the atypical character of the post-Soviet semi-presidentialism on the basis of such an indicator as the institution of vote of no confidence in governments. The purpose of the article is to determine features of functioning of the semi-presidential system of government and types of political regime in the Republic of Kazakhstan (in 1995-2018). As a result of the article, it is argued that parliamentary vote of no confidence in government does not automatically lead to government's resignation, since it depends on the position/will of a president in Republic of Kazakhstan. It determines the atypicality of semi-presidential (constitutional) system of government in the analyzed country. On the basis of methods The Democracy Score (for "Nations in Transit" program of "Freedom House") and The Economist Intelligence Unit's Democracy Index, types of the political regime in the Republic of Kazakhstan are defined. It is argued that the political regime in the Republic of Kazakhstan on the basis of The Democracy Score (in 1997-2018) evolved from semi-consolidated authoritarianism to consolidated authoritarianism. Moreover, it is argued that the political regime in the Republic of Kazakhstan on the basis of The Economist Intelligence Unit's Democracy Index (in 2006-2018) is defined as authoritarian. On the basis of F. Guliyev's research, the political regime in the Republic of Kazakhstan (in 19951997) is defined as hegemonic authoritarianism.

Key words: system of government, semi-presidential system of government, atypical semi-presidential system of government, vote of no confidence in government, political regime, Republic of Kazakhstan. 